in other non-legume nodule-forming genera. The distinctiveness of the Casuarina organism is thus confirmed. The roots springing from the nodule lobes are shown to be characterized by upward growth and in this to resemble remarkably closely the corresponding roots of Myrica. Nodulated plants of Casuarina are able to grow vigorously in culture solutions free of combined nitrogen, showing that fixation of atmospheric nitrogen occurs, amounting in $C$. cunninghamiana to $50 \mathrm{mgm}$. per plant during six months of active growth. The evidence indicates that the fixation occurs in the nodules, and that these have exactly the same functional significance as those of legumes (Ann. Bot., N.S., 21, $373 ; 1957)$.

\section{Annual Variation of Sporadic Meteors}

IN a paper on the theory of the annual variation of sporadic meteors (Pub. Astron. Soc. Japan, 8, Nos. 3-4; 1956), Tadayoshi Murakami, of the University of Hiroshima, explains that his reduction of the annual variation was undertaken to verify his drift motion hypothesis of interstellar meteoric particles, published under the title "On the Drift Motion of the Interstellar Meteors in the Vicinity of the Solar Systom" (Mem. Oriental Astron. Assoc., No. $152 ; 1954)$. In the present paper the author admits that most of the meteoric particles for sporadic meteors move together with the solar system, the variation being governed mainly by the altitude of the apex of the Earth's way. A comparison between the meteor rate deduced from observation and the altitude of the meteor apex shows that the relation is simple, and a theory is developed to explain this fact. While admitting that there is a discrepancy between theory and observation, it is pointed out that this can be ascribed to the irregular distribution of the density of the meteoric particles. The relation betwoen the number of meteors $m_{c}$ and the zenith distance of the meteor apex can be expressed by the empirical formula $m_{c}=12 \cdot 6$ cos $\zeta+6 \cdot 3$, where $76^{\circ}<\zeta<104^{\circ}$. The number of meteors calculated from this formula shows a satisfactory agreement between the observed and calculated variations (Pub. Astron. Soc. Japan, 8, 87; 1956). Although the true distribution of meteors is very different from uniform, as shown by the work of Lovell, Prentice, Hawkins and Aspinall, the author contends that, for a first approximation, uniformity of distribution must be postulated, irregularities of distribution being considored in the next step. On this assumption he derives a formula similar to that derived by Davidson (J. Brit. Astron. Assoc., 24, $352 ; 1914)$. The value of the heliocentric velocity obtained is $58.5 \mathrm{~km}$./sec., which does not agree with modern determinations of meteor velocities. It is admitted that the subject requires further consideration but the results suggest that there is unevenness of density distribution of meteoric particles.

\section{University News:}

Exeter

THE following appointments in the University of Exeter have recently been made: Mr. A. Stuart, to the newly created chair of geology ; Dr. K. E. Grew, to be reader in physics; G. A. Duller, as assistant lecturer in mathematics; Dr. H. P. Mulholland, as senior lecturer in mathematics; D. J. Stone, as lecturer in mathematical statisties; Dr. R. J. Williams, as lecturer in physical chemistry.

\section{Announcements}

Sir Solly Zuckerman, Sands Cox professor of anatomy in the University of Birmingham, has been awarded the Cross of Chevalier in the French national order of the Légion d'Honneur.

The Castner Gold Medal of the Society of Chemical Industry has been awarded for 1958 to Dr. R. Holroyd, deputy chairman of Imperial Chemical Industries, Ltd. The Medal was instituted to commemorate the work of Hamilton Young Castner and is one of the Society's senior awards. It is awardod every two years.

Trinity College, Cambridge, offers entrance exhibitions to male students of universities in the British Commonwealth to enable them to read for the degree of B.A. or LL.B., or for a diploma. Further information can be obtained from the Senior Tutor, Trinity College, Cambridge.

THe New Zealand Journal of Science and Technology is to be replaced at the beginning of 1958 by the New Zealand Journal of Agricultural Research (bi-monthly), the New Zealand Journal of Geology and Geophysics and the New Zealand Journal of Science (both quarterly).

AN exhibition of laboratory apparatus and teckniques will be held in the College of Science and Technology, Sackville Street, Manchester, on December 18, during 2-8 p.m., and on December 19 during 10 a.m.-8 p.m.

A HALF-DAY conference on "Production Control", organized by the Industrial Applications Section of the Royal Statistical Society, will be held on December 13 at the London School of Hygiene and Tropical Medicine, Keppel Street, London, W.C.1. The conference starts at 2 p.m. Further information can be obtained from A. N. James, Wynyates, Church Road, Watford, Herts.

The Institute of Physics has arranged a three-day conference on "Nuclear Fuel Cycles", to be held at the Institution of Civil Engineers during January $15-17,1958$. Further details can be obtained from the Institute of Physies, 47 Belgrave Square, London, S.W.1.

The 128th course of six Christmas lectures "adapted to a juvenile auditory" is to be delivered at the Royal Institution on December 28 and 31,1957 , and January $2,4,7$ and 9,1958 , at 3 p.m., by Dr. Julian S. Huxloy and Mr. James Fisher on the subject of "Birds". The lectures will deal with "Birds in the Animal Kingdom", "Birds and Flight", "Birds Past and Present", "Birds Rare and Common", "Bird Migration and Navigation", "Bird Watching". The first lecture will be given by Dr. Huxloy and the remaining five by Mr. Fisher. Applications for tickots (juveniles, aged 10-17, £1; adult non-members, £2) should be addressed to the Royal Institution, 21 Albemarle. Street, London, W.1.

Erratum. We regret to find that mistakes have occurred in numbering the axos of the graph which accompanied the communication entitled "Vitamin $\mathrm{B}_{12}$ in Marine Ecology" by M. R. Droop, in Nature of November 16, p. 1041. The ordinate graduations (numbor of cells per ml.) should be $10^{5}, 10^{6}$ and $10^{7}$ (reading upwards); the abscissa graduations (vitamin $\mathrm{B}_{12}(\mu \mu \mathrm{gm} . / \mathrm{ml}$.$) ) should be 0 \cdot 1,1 \cdot 0$ and 10 (reading left to right) and these numbers should appear immediately below the marks on the horizontal axis. 